
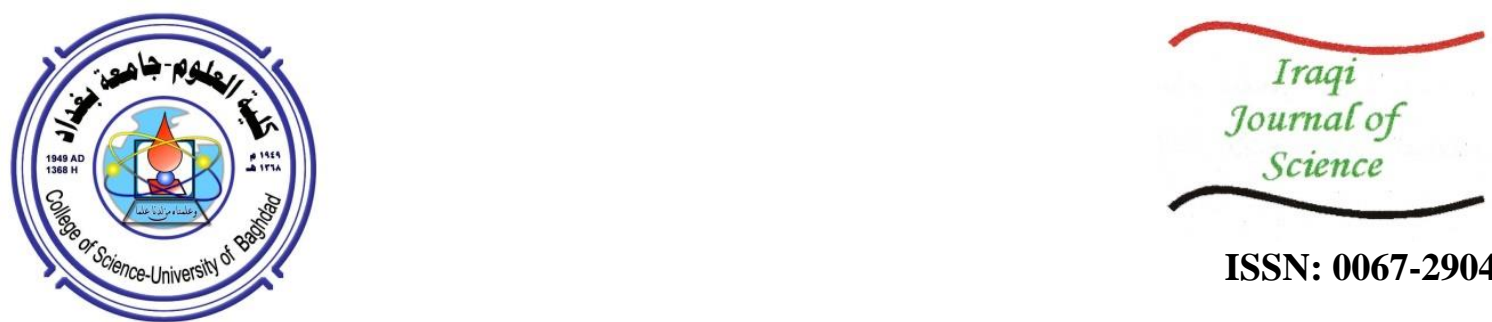

ISSN: 0067-2904

\title{
Antimicrobial Activity of Non-bond Colicin on Candida albicans Biofilm
}

\author{
Nayarah .S. Hussain*1, Ismail .I. Latif ${ }^{1}$, Hind .H. Obaid ${ }^{2}$ \\ ${ }^{1}$ Microbiology Department, College of Medicine, Dyiala University, Dyiala, Iraq \\ ${ }^{2}$ Biology Department, College of Science, University of Baghdad, Baghdad, Iraq
}

$$
\text { Received: 22/10/2019 Accepted: 17/12/2019 }
$$

\begin{abstract}
Two hundred fifty mid-stream urine specimens were collected from Baqubah Teaching Hospital and Al-Batool Teaching Hospital from patients with urinary tract infections (UTI). Of these investigated urine specimens, 66 (26.4\%) specimens showed positive growth culture of Gram-negative bacteria. From these, Escherichia coli was the most prevalent bacteria of the examined culture $(41,62.12 \%)$. Additionally, the cup assay was used to determine colicin producers while the most efficient colicin producers were estimated by the formation of larger inhibition zone. Approximately half of the investigated $E$. coli isolates $(20,49 \%)$ was colicin producers. Colicins was extracted after induction by mitomycin-C showed a concentration of $3020 \mu \mathrm{g} / \mathrm{ml}$, as estimated utilizing the Lowry method, while its activity was $80 \mathrm{U} / \mathrm{ml}$. Our study results showed that colicin had significant antibiofilm activity $(\mathrm{P} \leq 0.05)$ against Candida albicans and the effect seemed to be concentration dependent. . However, the values of biofilm inhibition varied depending on the different tested isolates. The biofilm of isolate 5 showed the most significant inhibition $(\mathrm{P} \leq 0.05)$ by colicin with a value of $46 \%$, while isolate 3 was less affected with an inhibition rate of $19 \%$ at the concentration of $2500 \mu \mathrm{l} / \mathrm{ml}$.
\end{abstract}

Keywords: Escherichia coli, Colicin, Candida albicans, Antibiofilm.

$$
\begin{aligned}
& \text { الفعالية الضد مايكروبية للكولسين الغير مرتبط على الاغشية الحيوية للمبيضات البيضاء } \\
& \text { نيره سامر حسين ^1, إسماعيل إبراهيم لطيف1', هند حسين عبيد² }
\end{aligned}
$$

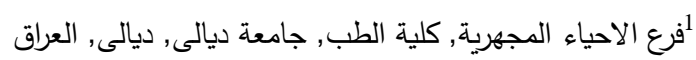

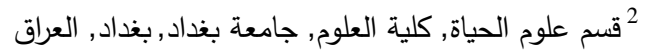

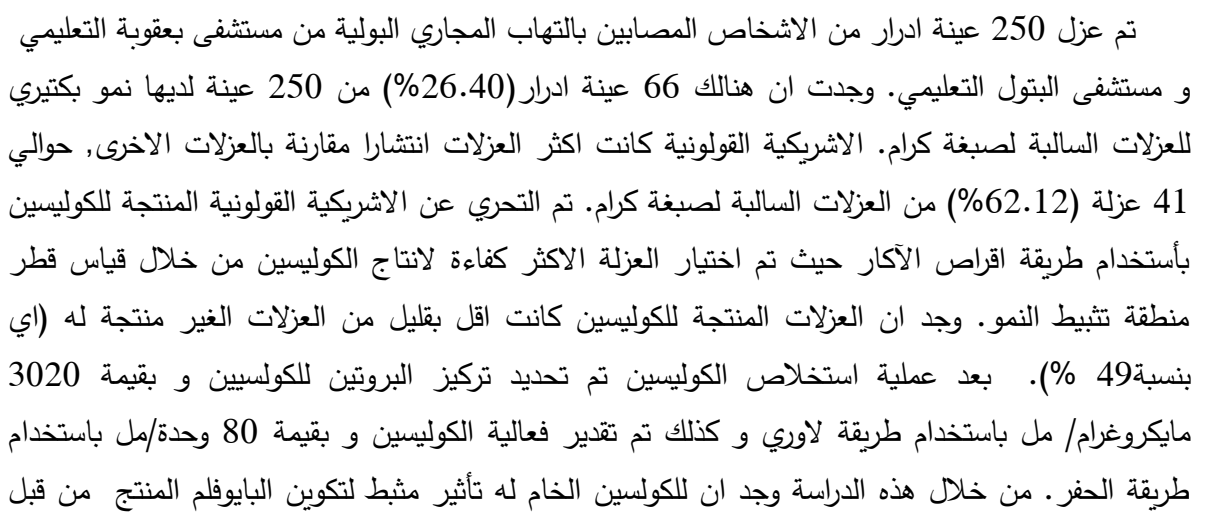




\section{Introduction}

$$
\begin{aligned}
& \text { المبيضات الفطرية وبصورة معنوية( PS0.05 ) (P) لوحظ انه كلما ازداد تركيز الكولسين كلما زاد معله التأثير }
\end{aligned}
$$

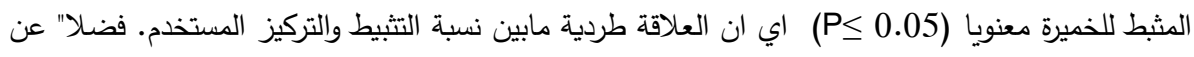

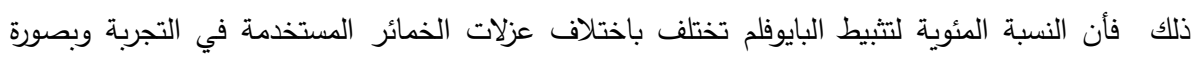

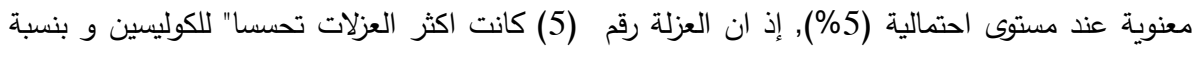

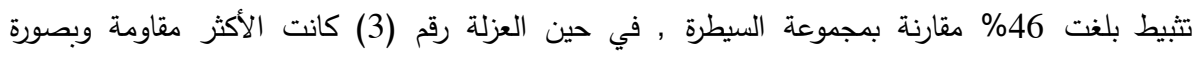

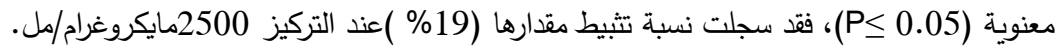

Escherichia coli is one of the most common pathogens, which causes a wide spectrum of diseases within and outside the intestinal tract[1]. Extraintestinal pathogenic E. coli (ExPEC) is the main causative agent of urinary tract infection, enteritis, septicemia and other infections such as neonatal meningitis [2]. One of its key pathogenicity features is the production of bacteriocins[3]. Bacteriocins are ribosomal synthesized antimicrobial peptides that have the ability to kill or inhibit the growth of other strains, without damaging the producing bacteria due to having specific immunity proteins [4]. These peptides are different in many features like molecular mass, the existence of post-translational modifications, mechanisms of bacteriocins release from producer cells, and others [5]. Genes of bacteriocin biosynthesis are clustered and encoded on plasmids, chromosome and/or transposons [6]. It is believed that the killing mechanism of colicins produced by $E$. coli can be accomplished by pore formation in the inner membrane of the target cell and degradation of intracellular components such as DNA and RNA [7].

Candida albicans is a dimorphic fungus that may be found as commensal in the oral cavity of healthy people, but it also causes recurrent, severe and even lethal systemic infections [8]. It is thought that the rising rate of immunocompromised patients could lead to increase the risk of candidiasis [9]. C. albicans can infect skin, mouth, throat and blood [10]. This may be attributed to the possession of many virulence factors that help C. albicans to infect the host. C. albicans virulence factors include polymorphism, adhesins and invasions, hydrolases, germ tube formation and biofilm [11]. Biofilm is a population of microorganisms attached to the solid surfaces and embedded in extracellular polymeric substances (EPS) that are composed of proteins, carbohydrates, and nucleic acids. Microorganisms usually produce these EPS matrix in a complex structure, which is comparable to honeycombs of the hive, that supports them as a mechanical defense and resistance against antimicrobials [12]. Patients can acquire infection due to the presence of biofilms on hospital equipment and medical devices, eventually leading to persistent infections [13].

There are several reasons to analyze the effect of colicin as antimicrobial against candida, such as the appearance of antimicrobial resistance candida and the side effects of these drugs as well as the spread of drug resistant biofilms.

\section{Materials and methods}

\section{Isolation and identification of bacterial and fungal isolates}

Mid-stream urine specimens were collected from Baqubah Teaching Hospital and Al-Batool Teaching Hospital from patients clinically diagnosed with urinary tract infections (UTI). The isolates were identified utilizing microscopic examination. Morphological features of the colonies and biochemical tests were conducted according to Brenner and Farmer[14] as well as by using chrome agar and Vitek-2 system.

C. albicans isolates were obtained from oral swabs from patients with renal impairment. C. albicans isolates detection was confirmed by forming germ tubes [15] and by Vitek-2 system.

\section{Detection of colicin-producing isolates}

Colicin-producing E. coli were detected using cup assay[16]. The most efficient producers showed the largest inhibition zone and the feature of the stability of bacteriocin production.

\section{Extraction of crude non-bound colicin.}

Previously incubated $2.5 \mathrm{ml}$ of nutrient broth with the selected colicin producer were added to sterile nutrient broth supplied with $5 \%$ of glycerol and then incubated for $14 \mathrm{~h}$ at $37{ }^{\circ} \mathrm{C}$. After the addition of $2 \mu \mathrm{g} / \mathrm{ml}$ of mitomycin-C, they were incubated in an incubator shaker for $3 \mathrm{hrs}$ then centrifuged at $5000 \mathrm{rpm}$ for $30 \mathrm{~min}$ using refrigerated centrifuge. The non-bound colicin in the supernatant was separated from the cells. To eradicate the remaining cells, chloroform was added. To confirm the bacterial clearance, the supernatant was cultured on brain heart infusion. The activity of 
colicin was detected by using the well method [17] and colicin concentration was estimated by Lowry method $[18,19]$.

\section{Biofilm formation of $C$. albicans}

After incubation of $C$. albicans isolates on sabouraud dextrose broth, they were diluted by sterile broth at the ratio of 1:20. Each well of the 96-well flat microtiter plates were filled with $200 \mu \mathrm{l}$ of these isolate suspensions. Sabouraud dextrose broth was also used as negative control in separate wells of the 96-well flat microtiter plate. Experiments were performed in triplicates in which the plates were incubated for $48 \mathrm{hrs}$ at $37{ }^{\circ} \mathrm{C}$. Following the incubation, the medium and the unbound cells were removed; the wells were washed by Phosphate Buffer Saline (PBS) then left to dry for 15 mins. $200 \mu 1$ of Crystal Violet (CV) were added to the wells and left for 20 mins. CV was removed and the plates were washed by PBS three times then left to dry at room temperature. $200 \mu \mathrm{l}$ of solution of acetone: ethanol (20:80) was added to each well and left for $10 \mathrm{~min}$. Plate reader apparatus (Biotek/ USA) was used for reading the results at $450 \mathrm{~nm}$. The optical density (OD) values were estimated, where the values $>0.320,0.120-0.320$, and $<0.120$ were considered as reflecting strong, moderate, and weak reactions, respectively [20].

\section{The inhibition of $C$. albicans biofilm formation}

The suspensions of $C$. albicans were inoculated to 96- flat well microtiter plates previously inoculated with colicin at Minimum Inhibitory Concentration (MIC) concentrations. After $48 \mathrm{hrs}$ of incubation, the wells were washed by PBS then left to dry. $200 \mu \mathrm{l}$ of CV was added for $20 \mathrm{~min}$. CV was removed and the plates were washed by PBS and left to dry. $200 \mu 1$ of acetone: ethanol solution (20:80) was added to the wells and left for $20 \mathrm{~min}$, then the result was read by the plate reader [21, 22]. Biofilm inhibition was calculated using the below equation [23]:

Inhibition of biofilm formation $\%=\frac{\text { OD control }- \text { OD treatment }}{\text { OD control }} \times 100$

\section{Results and discussion}

\section{Isolation and identification}

Out of 250 urine samples, 66 (26.4\%) isolates had bacterial growth, as shown in Figure-1. E. coli was the most prevalent Gram-negative bacteria in UTI samples, which was

recorded in $40(60.60 \%)$ of the 66 Gram-negative isolates ( Figure-2).

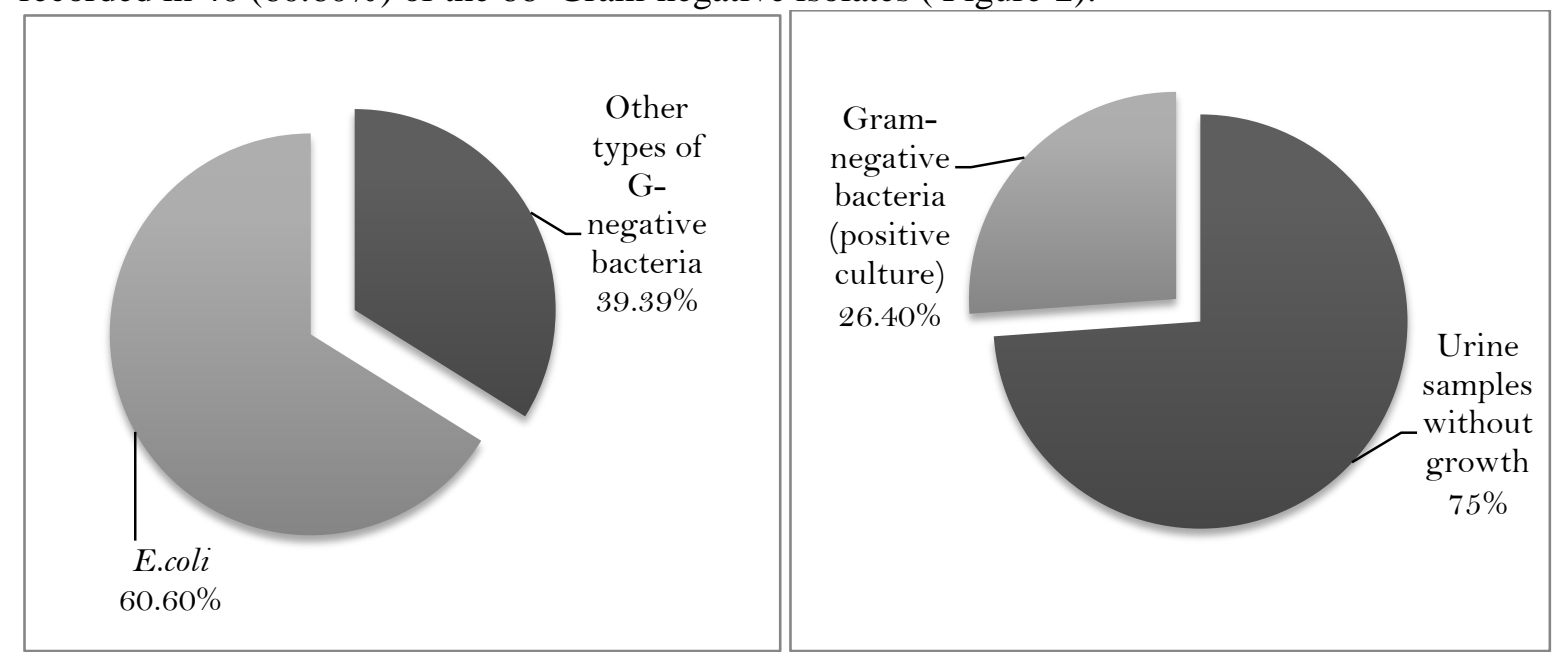

Figure 1-The percentage of bacterial growth with positive cultures from UTI isolated from UTI patients.
Figure 2-The percentage of E. coli

isolates among other G- bacteria urine specimens

In this respect, a previous study reported that the prevalence of E. coli $(38.90 \%)$ was higher than the other bacteria in UTI cases [24]. In this regard, several conditions may affect the prevalence of bacteria among patients. These may involve environmental, health, social, and cultural conditions of patients. In addition, the technical mistakes for isolation and identification of bacteria may give inconsistency in the reported findings[25].

Detection of colicin-producing $E$. coli by cup assay

By the detection of the inhibition zone using cup assay, we observed that 20 E. coli isolates (49\%) were colicin producers (Figure-3) and the most effective isolate had the larger inhibition zone. 
However, this result seems relatively different from the findings of a recent research [26] which illustrated that E.coli was the most colicin producing bacterial isolate which was produced by 36 (30.77\%) out of 117 E.coli isolates. These differences occur due to several reasons such as the components of the used media [27] and the different methods used for the detection of colicin production [28]. Another study reported that the use of the cup assay and the addition of 5\% glycerol gives robust results for the detection of bacteriocin producers [29].

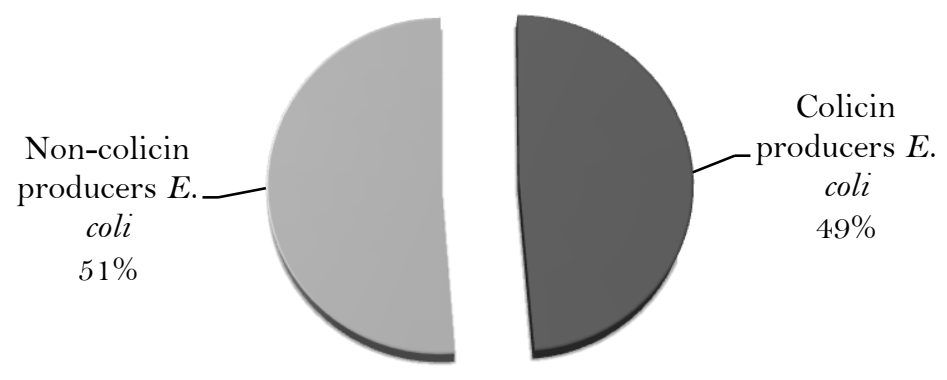

Figure 3-Percentage of cup assay of colicin producing E. coli isolated from UTI patients.

\section{Biofilm formation of $C$. albicans}

Biofilm formation of C.albicans was assessed by the microtiter plate method [20]. The isolates 2 and 5 were found to form strong biofilms and their optical density values were 0.36 and 0.337 , respectively, while moderate biofilms were found to be formed by the others isolates, with optical density ranged from 0.249 for isolate 1 to 0.313 for isolate 7 ( Table-1).

Table 1-Values of Tissue Culture Plate (TCP) method of biofilm formation of C. albicans isolated from oral swabs of patients with renal impairment

\begin{tabular}{|c|c|c|}
\hline C.albicans isolates & OD & $\begin{array}{c}\text { Estimation of biofilm } \\
\text { formation }\end{array}$ \\
\hline C1 & 0.249 & Moderate \\
\hline C2 & 0.36 & Strong \\
\hline C3 & 0.269 & Moderate \\
\hline C4 & 0.278 & Moderate \\
\hline C5 & 0.337 & Strong \\
\hline C6 & 0.276 & Moderate \\
\hline C7 & 0.313 & Moderate \\
\hline C8 & 0.312 & Moderate \\
\hline
\end{tabular}

An earlier study showed that $C$. albicans colonizing the oral cavity can form a biofilm on saliva coating areas [30]. Consistence with our finding, Udayalaxmi and Shenoy reported that $45.83 \%$ of Candida species were strong or moderate biofilm formers while the percentage of isolates that produce weak biofilm in their study was $54.16 \%$ [31].

\section{Inhibition of biofilm formation by non-bond colicin}

The results of biofilm inhibition were dependent on the concentration of colicin and the type of indicator E. coli isolate. This was evident when the higher concentrations of colicin led to significantly $(\mathrm{P} \leq 0.05)$ increased inhibition of biofilm; . Thus, the relation between the extracted colicin concentration and the biofilm inhibition is inversely proportional in the tested C. albicans isolates . 
Table 2-Inhibition of biofilm formation by non-bond colicin extracted from E. coli isolated from UTI patients.

\begin{tabular}{|c|c|c|c|c|c|c|c|c|c|}
\hline \multirow{2}{*}{$\begin{array}{c}\text { Concentration } \\
\text { of colicin } \\
\mu \mathrm{g} / \mathrm{ml}\end{array}$} & \multicolumn{8}{|c|}{ Inhibition of biofilm formation $\%$} & \multirow{2}{*}{$\begin{array}{l}\text { LSD } \\
\text { value }\end{array}$} \\
\hline & $\mathrm{C} 1$ & $\mathrm{C} 2$ & $\mathrm{C} 3$ & $\mathrm{C} 4$ & $\mathrm{C} 5$ & C6 & $\mathrm{C} 7$ & $\mathrm{C} 8$ & \\
\hline 19.53 & 20 & 3 & 3 & 1 & 21 & 12 & 6 & 6 & $5.72 *$ \\
\hline 39.06 & 30 & 3 & 5 & 7 & 27 & 20 & 6 & 6 & $5.36^{*}$ \\
\hline 78.125 & 33 & 3 & 5 & 13 & 34 & 22 & 7 & 9 & $5.09^{*}$ \\
\hline 156.25 & 33 & 3 & 7 & 16 & 35 & 22 & 9 & 16 & $4.66^{*}$ \\
\hline 312.5 & 35 & 18 & 8 & 17 & 36 & 25 & 18 & 19 & $5.38^{*}$ \\
\hline 625 & 39 & 21 & 10 & 19 & 36 & 29 & 23 & 20 & $6.01 *$ \\
\hline 1250 & 39 & 29 & 16 & 30 & 43 & 33 & 29 & 21 & $5.82^{*}$ \\
\hline 2500 & 43 & 31 & 19 & 39 & 46 & 39 & 39 & 33 & $6.39 *$ \\
\hline LSD value & $6.42 *$ & $5.77 *$ & $5.61 *$ & $6.03 *$ & $7.29 *$ & $7.53 *$ & $6.21 *$ & $6.64 *$ & --- \\
\hline
\end{tabular}

$*(\mathrm{P}<0.05)$.

The results demonstrated in Table- 2 show that all $C$. albicans isolates were inhibited significantly $(\mathrm{P} \leq 0.05)$ by colicin, but their sensitivity was variant depending on the isolates. The isolates 1 and 5 were the most sensitive to colicin at the concentration $2500 \mu \mathrm{g} / \mathrm{ml}$, with inhibition of biofilm values of $43 \%$ and $46 \%$, respectively. At the same concentration, isolate 3 was the less sensitive isolate that showed a value of biofilm inhibition of $19 \%$. There are some explanations of colicin action on the biofilm of microorganisms. Some bacteriocins act by disrupting the co-aggregation process of the membranes which is important for biofilm stability; thus it decreases biofilm development by reducing its biomass and thickness [32].

Other bacteriocins cause pore formation that results in an efflux of ATP from biofilm cells. The size of pores has to be larger than 1.5 in diameters which is enough to cause efflux of ATP [33]. Moreover, some bacteriocins have the ability to suppress biofilm genes such as atl (autolysin) and ica (intercellular adhesin) such as bacteriocin gallidermin [34].

Furthermore, ColA-43862 produced by Citrobacter freundii is known to have anti-biofilm activity, but it may not act as a limiting factor due to the complication of biofilm and its microenvironment that act as a barrier of colicins action [35].

An earlier study reported that a bacteriocin of Lactobacillus acidophilus had remarkably reduced biofilm cells of catheter-associated multidrug-resistance Pseudomonas aeruginosa. This bacteriocin can act as an alternative for antibiotics that hardly eliminate biofilm of $P$. aeruginosa [36]. A recent study reported that a bacteriocin of Bacillus subtilis (subtilocin) caused biofilm inhibition of Gardnerella vaginalis, with an inhibition value higher than $90 \%$, however, it did not decrease the growth of planktonic cells. Also, it remarkably inhibited the biofilm of E. coli and L. monocytogenes. Inhibition of biofilm by these bacteria occurs because of their ability to inhibit the quorum sensing (QS) [37]. Bacteriocin EntV of Enterococcus faecalis has a reduction activity on virulence factors of C. albicans without affecting the viability of cells. It blocks hypha formation, which results in preventing biofilm formation as well as reducing inflammation and invasion of the epithelium by candida in marine models [38].

\section{Conclusions}

Biofilm of C. albicans was significantly inhibited $(\mathrm{P} \leq 0.05)$ by crude non-bond colicin and the inhibition effect was more evident at high concentrations of the extracted colicin. However, the biofilm inhibition effect of the $E$. coli extracted colicin seemed to be $C$. albicans isolates-specific as some isolates were more sensitive to colicin while others were less affected.

\section{References}

1. Jaureguy, F., Landraud, L., Passet, V., Diancourt, L., Frapy, E., Guigon, G., Carbonnelle, E., Lortholary, O., Clermont, O., Denamur, E. and Picard, B. 2008. Phylogenetic and genomic diversity of human bacteremic Escherichia coli strains. BMC genomics, 9(1): 560. doi: $\underline{10.1186 / 1471-2164-9-560 .}$ 
2. Allocati, N., Masulli, M., Alexeyev, M.F. and Di Ilio, C. 2013. Escherichia coli in Europe: an overview. International journal of environmental research and public health, 10(12): 6235-6254. doi: 10.3390/ijerph10126235.

3. Budič, M., Rijavec, M., Petkovšek, Ž. and Žgur-Bertok, D. 2011. Escherichia coli bacteriocins: antimicrobial efficacy and prevalence among isolates from patients with bacteraemia. PLoS One, 6(12): e28769. doi: 10.1371/journal.pone.0028769.

4. Azpiroz, M.F., Poey, M.E. and Laviña, M. 2009. Microcins and urovirulence in Escherichia coli. Microbial pathogenesis, 47(5): 274-280. doi: 10.1016/j.micpath.2009.09.003.

5. Silva, C.C., Silva, S.P. and Ribeiro, S.C. 2018. Application of bacteriocins and protective cultures in dairy food preservation. Frontiers in microbiology, 9(1): 594. doi: 10.3389/fmicb.2018.00594.

6. Klaenhammer, T.R. 1993. Genetics of bacteriocins produced by lactic acid bacteria. FEMS microbiology reviews, 12(1-3):39-85. DOI: 10.1111/j.1574-6976.1993.tb00012.x.

7. Jin, X., Kightlinger, W., Kwon, Y.C. and Hong, S.H. 2018. Rapid production and characterization of antimicrobial colicins using Escherichia coli-based cell-free protein synthesis. Synthetic Biology, 3(1): ysy004. https://doi.org/10.1093/synbio/ysy004.

8. Noble, S.M., Gianetti, B.A. and Witchley, J.N. 2017. Candida albicans cell-type switching and functional plasticity in the mammalian host. Nature Reviews Microbiology, 15(2): 96. doi: 10.1038/nrmicro.2016.157.

9. Sellam, A. and Whiteway, M. 2016. Recent advances on Candida albicans biology and virulence. F1000Research, 5: 2582. doi: 10.12688/f1000research.9617.1.

10. Mayer, F.L., Wilson, D. and Hube, B. 2013. Candida albicans pathogenicity mechanisms. Virulence, 4(2): 119-128. doi: 10.4161/viru.22913.

11. De Souza, P.R., De Andrade, D., Cabral, D.B. and Watanabe, E. 2014. Endotracheal tube biofilm and ventilator-associated pneumonia with mechanical ventilation. Microscopy research and technique, 77(4): 305-312. doi: 10.1002/jemt.22344.

12. Hall, C.W. and Mah, T.F. 2017. Molecular mechanisms of biofilm-based antibiotic resistance and tolerance in pathogenic bacteria. FEMS microbiology reviews, 41(3):276-301. doi: 10.1093/femsre/fux010.

13. Garsin, D.A. and Lorenz, M.C. 2013. Candida albicans and Enterococcus faecalis in the gut: synergy in commensalism?. Gut microbes, 4(5):409-415. doi: 10.4161/gmic.26040.

14. 14-Brenner, D.J. and Farmer III J. J. 2005. Family I. Enterobacteriaceae. In: Brenner, D. J., Krieg, N. R., and (eds), Bergey's Manual of Systematic Bacteriology, 2nd edition. New York: Springer. 587-607.

15. Matare, T., Nziramasanga, P., Gwanzura, L. and Robertson, V. 2017. Experimental Germ Tube Induction in Candida albicans: An Evaluation of the Effect of Sodium Bicarbonate on Morphogenesis and Comparison with Pooled Human Serum. BioMed research international, 2017. doi: $10.1155 / 2017 / 1976273$.

16. Al-Qassab, A.O. and Al-Khafaji, Z.M. 1992. Effect of different conditions on inhibition activity of enteric lactobacilli against diarrhea-causing enteric bacteria. Journal of Agricultural Science, 3(1): $18-26$.

17. Herschman, H.R. and Helinski, D.R. 1967. Purification and characterization of colicin E2 and colicin E3. Journal of Biological Chemistry, 242(22): 5360-5368. http://www.jbc.org/content/242/22/5360.

18. Smajs, D., Pilsl, H. and Braun, V. 1997. Colicin U, a novel colicin produced by Shigella boydii. Journal of bacteriology, 179(15): 4919-4928. doi: 10.1128/jb.179.15.4919-4928.1997.

19. Lowry, O.H., Rosebrough, N.J., Farr, A.L. and Randall, R.J. 1951. Protein measurement with the Folin phenol reagent. Journal of biological chemistry, 193: 265-275. https://www.ncbi.nlm.nih.gov/pubmed/14907713.

20. Deepa, K., Jeevitha, T. and Michael, A. 2015. In vitro evaluation of virulence factors of Candida species isolated from oral cavity. Journal of Microbiology and antimicrobials, 7(3):28-32. https://doi.org/10.5897/JMA2015.0337.

21. Dhanasekaran, D., Vinothini, K., Latha, S., Thajuddin, N. and Panneerselvam, A. 2014. Human dental biofilm: Screening, characterization, in vitro biofilm formation and antifungal resistance of Candida spp. The Saudi Journal for Dental Research, 5(1): 55-70. https://doi.org/10.1016/j.ksujds.2013.10.001. 
22. Ali, O.A.U. 2012. Prevention of Proteus mirabilis biofilm by surfactant solution. Egypt Academic Journal of Biological Science, 4:1-8. http://microbiology.eajbs.eg.net/pdf/vol4.n1/1.pdf.

23. Chevalier, M., Medioni, E. and Prêcheur, I. 2012. Inhibition of Candida albicans yeast-hyphal transition and biofilm formation by Solidago virgaurea water extracts. Journal of medical microbiology, 61(7):1016-1022. doi: 10.1099/jmm.0.041699-0.

24. Majeed, H.T. and Aljanaby, A.A.J. 2019. Antibiotic Susceptibility Patterns and Prevalence of Some Extended Spectrum Beta-Lactamases Genes in Gram-Negative Bacteria Isolated from Patients Infected with Urinary Tract Infections in Al-Najaf City, Iraq.Avicenna journal of medical biotechnology, 11(2):192. https://europepmc.org/article/med/31057723.

25. Salman, S.B. and Al-Mathkhury, H.J.F. 2016. Molecular Detection of Klebsiella pneumoniae serotype K2 Isolated Clinically. Iraqi Journal of Science, 57(1A):98-103. https://pdfs.semanticscholar.org/3cec/12808875845b27433963922156b14e588be1.pdf.

26. Obaid, H.H. 2016. Detection of Bacteriocin Production and Induction by Brassica rapa extract. Ibn AL-Haitham Journal for Pure and Applied Science, 29(3):234-248. http://ircoedu.uobaghdad.edu.iq/jih/index.php/j/article/view/714.

27. Richardson, H., Emslie-Smith, A.H. and Senior, B.W. 1968. Agar diffusion method for the assay of colicins. Applied and Environmental Microbiology, 16(10):1468-1474. https://aem.asm.org/content/16/10/1468.

28. Özdemir, G.B., Oryaşın, E., Bıyık, H.H., Özteber, M. and Bozdoğan, B. 2011. Phenotypic and genotypic characterization of bacteriocins in enterococcal isolates of different sources. Indian journal of microbiology, 51(2):182-187. doi: 10.1007/s12088-011-0143-0.

29. Al-Charrakh, A.H., Yousif, S.Y. and Al-Janabi, H.S. 2011. Antimicrobial spectrum of the action of bacteriocins from Klebsiella isolates from Hilla/Iraq. Iranian Journal of Microbiology, 2(5):7678. https://www.iasj.net/iasj?func=fulltext\&aId=140076.

30. Bamford, C.V., d'Mello, A., Nobbs, A.H., Dutton, L.C., Vickerman, M.M. and Jenkinson, H.F. 2009. Streptococcus gordonii modulates Candida albicans biofilm formation through intergeneric communication. Infection and immunity, 77(9):3696-3704. doi: 10.1128/IAI.00438-09.

31. Udayalaxmi, J. and Shenoy, N. 2016. Comparison between biofilm production, phospholipase and haemolytic activity of different species of Candida isolated from dental caries lesions in children. Journal of clinical and diagnostic research,10(4):DC21. doi: 10.7860/JCDR/2016/17019.7643.

32. Shin, J.M., Ateia, I., Paulus, J.R., Liu, H., Fenno, J.C., Rickard, A.H. and Kapila, Y.L. 2015. Antimicrobial nisin acts against saliva derived multi-species biofilms without cytotoxicity to human oral cells, Frontiers in microbiology, 6:617. doi: 10.3389/fmicb.2015.00617.

33. McAuliffe, O., Ryan, M.P., Ross, R.P., Hill, C., Breeuwer, P. and Abee, T. 1998. Lacticin 3147, a broad-spectrum bacteriocin which selectively dissipates the membrane potential. Applied and Environmental Microbiology, https://www.ncbi.nlm.nih.gov/pmc/articles/PMC106063/.

64(2):439-445.

34. Zoll, S., Schlag, M., Shkumatov, A.V., Rautenberg, M., Svergun, D.I., Götz, F. and Stehle, T. 2012. Ligand-binding properties and conformational dynamics of autolysin repeat domains in staphylococcal cell wall recognition. Journal of bacteriology, 194(15):3789-3802. doi: 10.1128/JB.00331-12.

35. Shanks, R.M., Dashiff, A., Alster, J.S. and Kadouri, D.E. 2012. Isolation and identification of a bacteriocin with antibacterial and antibiofilm activity from Citrobacter freundii. Archives of microbiology, 194(7):575-587. doi: 10.1007/s00203-012-0793-2.

36. Al-Mathkhury, H.J.F., Ali, A.S. and Ghafil, J.A. 2011. Antagonistic effect of bacteriocin against urinary catheter associated Pseudomonas aeruginosa biofilm. North American journal of medical sciences, 3(8):367. doi.org/10.4297\%2Fnajms.2011.3367

37. Algburi, A., Zehm, S., Netrebov, V., Bren, A.B., Chistyakov, V. and Chikindas, M.L. 2017. Subtilosin prevents biofilm formation by inhibiting bacterial quorum sensing. Probiotics and antimicrobial proteins, 9(1):81-90. doi: 10.1007/s12602-016-9242-x.

38. Graham, C.E., Cruz, M.R., Garsin, D.A. and Lorenz, M.C. 2017. Enterococcus faecalis bacteriocin EntV inhibits hyphal morphogenesis, biofilm formation, and virulence of Candida albicans. Proceedings of the National Academy of Sciences, 114(17):4507-4512. doi: $\underline{10.1073 / \text { pnas.1620432114. }}$ 